\title{
Elucidation of genetic diversity among some accessions of sugar beet (Beta vulgaris L.) using inter-simple sequence repeats (ISSR) markers
}

\author{
Almoataz Bellah Ali El-Mouhamady ${ }^{1 *}$, Magdy Ahmad Al-Kordy ${ }^{1}$ and Tarik Abdel-Fatah Elewa ${ }^{2}$
}

\begin{abstract}
Background: Sugar beet is considered a very important strategic economic crop, as it comes at the second place for white sugar production in Egypt after sugar cane and the sugar percentage in its roots is 20\%. This work was conducted in Egypt as a direct response to bridge the gap which began to expand significantly between the production and consumption of white sugar and the desire for the genetic improvement process to increase the productivity of this crop. Further, as serious attempt to understand the nature of the genetic diversity among a group of sugar beet accessions with different origins, it constitutes an important source for establishing a program of breeding and improving sugar beet crop under Egyptian conditions.

Results: The process of verifying the existence of significant genetic variation between the eight sugar beet varieties with various origins was carried out through a set of genetic parameters through two growing seasons besides, the data of ISSR markers profile. Further, all the sugar beet varieties were superior in all the studied traits during their evaluation over two agricultural years, where the two sugar beet accessions Oscar Poly and Rass Poly are superior in TSS \% and sucrose \% traits, Mont Bianco and Sultan in apparent purity \% trait, Blino and Sultan in root yield and top yield traits and Rass Poly and Blino in sugar yield trait, respectively. In addition, the values of heritability in broad sense were high in all studied traits except the two traits; sucrose \% and sugar yield where their results were appeared medium during both growing seasons. In the same regard, expected genetic advance values showed significant genetic progress in all studied traits during the two growing seasons. As well, highly genetic diversity was obtained between the eight sugar beet accessions through generated 169 amplified fragments from the twelve ISSR primers, 122 of them were polymorphic with $72.18 \%$ polymorphism.
\end{abstract}

Conclusions: The eight sugar beet varieties achieved remarkable and distinctive results for all traits under study during two agricultural years. However, they were differentiated and various from each other. As they differed in their superiority in all estimated traits and they proved to be fertile material for studying in this investigation and very suitable for enriching the breeding and genetic improvement program to promote the sugar beet yield in order to increase the productivity of white sugar in Egypt.

Keywords: Sugar beet, Genetic diversity, Heritability, Genetic advance, ISSR markers

*Correspondence: elmouhamady@yahoo.com

${ }^{1}$ Genetic Engineering and Biotechnology Research Division, Genetics and Cytology Department, National Research Centre, 33 El Buhouth ST., Dokki, Cairo 12622, Egypt

Full list of author information is available at the end of the article

\section{Background}

Sugar beet (Beta vulgaris L.) is grown for the purpose of producing white sugar from roots mainly. They are conical in shape and white and contain sucrose at rates ranging between 15 and $20 \%$ on average and were selected from fodder beet. Yield and sugar traits were improved through selection and different breeding methods. In 
addition, sugar beet accounts about $25 \%$ of the total global demand for white sugar (Draycott 2006) and at present, this percentage may range from 40 to $45 \%$. As well, sugar beet is deeming the second important source for sugar production not only in Egypt, but internationally. Nearly from $66 \%$ of white sugar production in Egypt comes from both sugar cane and sugar beet. Therefore, the Egyptian state resorted to compensating for this lack of local production by importing from several countries and of course this constitutes a great stress on the Egyptian economy. Whatever, increasing the cultivated area besides, increasing the sugar production per unit area is an imperative and necessary to bridge the gap between the production and consumption of white sugar in Egypt.

Two distinct subgroups of sugar beet matching together with good form by using 23 SSR markers were discovered by Li et al. (2010). Knowledge of genetic diversity and the mechanisms of trait inheritance are among the most important scientific bases that can be used in the simple selection process for the purpose of genetic development and improvement in plant breeding programs (IzadiDarbandi et al. 2013). Abbasi et al. (2014) revealed the genetic diversity in sugar beet through estimating some agro-morphological traits and SSR markers and detected that 43 and $32.6 \%$ of the total genetic variability in agromorphological attributes could recognize salt-stress and drought tolerant parents. Ganapati et al. (2015) studied the genetic variability, heritability and genetic advance in quantitative traits of some sugar beet accessions through using gamma rays and clarified the genetic diversity and genetic improvement induced through the mutations in M1 generation.

Genetic diversity and relationship in sugar beet pollinators based on SSR markers were reported by TaskiAjdukovic et al. (2017) whom discovered 129 alleles with average of 3.2 alleles for each SSR marker responsible for genetic diversity among sugar beet genotypes. Genetic diversity between planted beets (Beta vulgaris) evaluated via population-across whole genome sequence by
Galewski and Mcgrath (2020) which they confirmed that the relative contributions of specific chromosomes were succeed to genome wide compare, where each chromosome detecting a various pattern of differentiation with related to crop type. Abou-Elwafa et al. (2020) studied genetic diversity in some sugar beet accessions under various conditions and showed that the two sugar beet accessions, namely USKPS25 and USC944-6-68 exhibited highly yield, quality and tolerance under both irrigation conditions (irrigated and water stress) and heat stress and must be exploited these materials in the sugar beet breeding and improvement programs.

For the sake of genetic improvement to increase the production of white sugar in this important crop, it was necessary to import a large group of genetic materials superior in sugar production and cultivate them under Egyptian conditions to test the degree of their adaptation to the environment and study the genetic diversity of these imports. As a serious attempt to benefit from it in a program of breeding and improving the sugar beet crop and increasing its final production from the roots and then producing white sugar.

\section{Methods \\ Genetic materials}

The present investigation was carried out in the research station in Aga center, Dakahlia Governorate, Egypt using eight sugar beet accessions with different origin in seasons $2017 / 2018$ and $2018 / 2019$. This study aimed to study the genetic diversity, genetic behavior and the extent of adaptation to the Egyptian environment in 8 sugar beet genotypes (Table 1 ). The preceding summer crop was rice in both seasons.

\section{Sowing}

Sugar beet balls (3-5 balls/hill) were hand sown using dry planting method on one side of the ridge in hills $20 \mathrm{~cm}$ apart in the half of October in both growing seasons and irrigation process was done immediately after

Table 1 The Origin of 8 sugar beet entries

\begin{tabular}{lllll}
\hline Serial of genotypes & Name & Source of materials & Type of development & Reaction for diseases \\
\hline G1 & Baraca & Egypt & Local variety & Resistance \\
G2 & B2001 & Egypt & Local variety & Resistance \\
G3 & Sultan & Egypt & Local variety & Resistance \\
G4 & Mont Bianco & Germany & Imported from Germany & Resistance \\
G5 & Oscar Boly & Denmark & Imported from Holland & Resistance \\
G6 & Blino & Holland & Imported from Sweden & Resistance \\
G7 & Rass poly & Sweden & Imported from Hungary & Resistance \\
G8 & Pita poly terry & Hungary & Resistance \\
\hline
\end{tabular}


sowing. Sugar beet plants were thinned to one plant/hill $(35,000$ plants/fed $)$ at the age of 35 days from planting and the recommended agricultural practices for growing sugar beet plants were followed according to The Sugar Crops Research Institute recommendation.

Note that, each variety was cultivated in three replicates in a randomized complete plot design for each growing season.

Irrigation method Sprinkler irrigation.

\section{Studied traits}

At harvest time, 15 plants were randomly chosen from the outer ridges of each replicate to determine the following traits:

1. TSS \% it was calculated in juice of fresh roots by using hand refract meter.

2. Sucrose \% it was determined Polari metrically on lead acetate extract of fresh maceleveld roots according to the method of Curruthers and Oldfield (1961).

3. Apparent purity $\%$ it was calculated as a ratio between sucrose $\%$ and TSS \% of roots as the method outlined by Curruthers and Oldfield (1961).

Plants that produced from the two inner ridges of each replicate at harvesting time were collected and cleaned. Then, roots and tops were sepaleveld and weighted in $\mathrm{Kg}$ and converted to calculate:

4. Root yield $(\mathrm{t} / \mathrm{fed})$.

5. Top yield ( $\mathrm{t} / \mathrm{fed})$.

6. Sugar yield ( $t / f e d)$ it was measured by multiplying root yield by sucrose $\%$.

\section{Statistical analysis}

Data obtained from all studied traits of the eight sugar beet accessions were analyzed using the SPSS ver.17, and analysis of variance was detected as recorded by Gomez and Gomez (1984).

\section{Estimates of genetic parameters}

Variance components, heritability in broad sense, genetic coefficient of variability (GCV \%), phenotypic coefficient of variability $(\mathrm{PCV} \%), \mathrm{D}^{\mathrm{z}}$ or the difference between the phenotypic coefficient of variation (PCV \%) and genotypic coefficient of variation (GCV \%), expected genetic advance (GA) in addition, the genetic advance as percentage of mean (GAM) were the most important measurements calculated through the two seasons in this study as follows:

The genetic coefficient of variability (GCV \%) and phenotypic coefficient of variability (PCV \%) were estimated according to the method suggested by Burton and Devane (1953). This evidence is considered extremely important because genotypic coefficient of variation largely represents the role of the additive, dominance and their various interactions besides, their direct impact on the process of inheriting important attributes, which represent the top goals of breeding for plant breeders for improving sugar beet yield. As for the phenotypic coefficient of variance, it represents the sum of the environmental and genetic variance, specifically the limit of the environmental impact or the environmental error, which in most cases must be very small to a negligible degree that does not affect the inheritance of important quantitative traits.

Estimation of heritability in broad sense Broad sense heritability $\left(h^{2}\right)$ expressed as the percentage of the ratio of the genotypic variance $(\mathrm{g} v)$ to the phenotypic variance (ph v) and was estimated on genotype mean basis as described by Burton and de Vane (1953) and Jonhson et al. (1955).

$D^{z}$ The difference between the phenotypic coefficient of variation (PCV \%) and genotypic coefficient of variation (GCV \%).

Estimation of genetic advance The expected genetic advance (GA) and percentage of the mean (GAM) assuming selection of superior $5 \%$ of the genotypes was estimated in accordance with the methods illustrated by Johnson et al. (1955).

\section{Molecular characterization}

Molecular genetics this important branch of genetics is a very important and essential step to explore and clarify the genetic differences between the eight genotypes of sugar beet, but on the molecular level. This work comes in the second place in the midst of the objectives of this investigation for determining degrees of genetic diversity among 8 sugar beet accessions. Besides, indicating the extent of compatibility and differences between these varieties with different origin. On this basis, the use of molecular genetic markers was not only evidence for the genetic differences between these sugar beet genotypes, but served as the taxonomic basis for these genetic materials. In addition, it greatly emphasized their great efficiency in terms of environmental adaptation. From this point of view, 12 ISSR primers, which had the greatest merit in clarifying and discovering the most important molecular genetic differences between the eight sugar beet varieties, were used in this context in Table 2. In addition, drawing the phylogenetic tree or cluster analysis for the genetic similarity among them and the following is a detailed explanation in this regard.

Note that, from the scientific and practical secretariat, it can be said that a large number of ISSR primers were 
Table 2 Name and sequences of the selected ISSR primers used in ISSR analysis profile

\begin{tabular}{|c|c|c|c|c|c|}
\hline No & Primer name & Sequence & No & Primer name & Sequence \\
\hline 1 & ISSR-1 & $5^{\prime}$-AGAGAGAGAGAGAGAGYC-3' & 7 & ISSR-7 & 5'-GACGATAGATAGATAGATA-3' \\
\hline 2 & ISSR-2 & $5^{\prime}$-AGAGAGAGAGAGAGAGYG-3' & 8 & ISSR-8 & 5'-AGACAGACAGACAGACGC-3' \\
\hline 3 & ISSR-3 & $5^{\prime}$-ACACACACACACACACYT-3' & 9 & ISSR-9 & 5'-GATAGATAGATAGATAGC-3' \\
\hline 4 & ISSR-4 & $5^{\prime}-A C A C A C A C A C A C A C A C Y G-3^{\prime}$ & 10 & ISSR-10 & 5'-GACAGACAGACAGACAAT-3' \\
\hline 5 & ISSR-5 & 5'-GTGTGTGTGTGTGTGTYG-3' & 11 & ISSR-11 & $5^{\prime}-\mathrm{ACACACACACACACACYA-3^{ \prime }}$ \\
\hline 6 & ISSR-6 & $5^{\prime}$-CGCGATAGATAGATAGATA-3' & 12 & ISSR-13 & 5'-AGAGAGAGAGAGAGAGYT-3' \\
\hline
\end{tabular}

Fig. 1 DNA Ladder: The molecular weights of marker used are 100,
200, 300, 400, 500, 600, 700, 800, 900, 1000, 1200, 1500, 2000 and
3000 bp, respectively

used, more than 12 primers. But, the 12 ISSR primers only used in this investigation were indeed the ones that succeeded in finding genetic differences and achieved the successful comparison between the eight sugar beet cultivars, which showed great benefit in this regard.

\section{DNA extraction and PCR}

The fresh leaves of the eight sugar beet plants was frozen in liquid nitrogen and ground to a fine powder using prechilled mortar and pestle. The powdered material was used for genomic DNA extraction by DNeasy kit following the manufacturer's instructions. The obtained DNA purity and concentration were determined by running on $1 \%$ agarose gel and using Nanophotometer.

\section{Inter sample sequence repeat (ISSR) analysis ISSR-PCR reactions}

The amplification reaction was carried out in $25 \mu \mathrm{l}$ reaction volume containing $1 \mathrm{X}$ PCR buffer, $2 \mathrm{mM} \mathrm{MgCl}$, 0.2 mM dNTPs, 25 pmol primer, $1 \mathrm{U}$ Taq DNA polymerase and $30 \mathrm{ng}$ template DNA (Fig. 1).

\begin{tabular}{ll}
\hline 5xbuffer & $5 \mu l$ \\
Mgcl2 $(25 \mathrm{mM})$ & $2 \mu \mathrm{l}$ \\
dNTPs $(10 \mathrm{mM})$ & $0.5 \mu \mathrm{l}$ \\
Primer (10 pmol) (RAPD) & 2.5 \\
\hline
\end{tabular}

\begin{tabular}{ll}
\hline DNA $(10 \mathrm{ng} / \mu \mathrm{l})$ & $3 \mu \mathrm{l}$ \\
Taq DNA Polymerase $(5 \mathrm{u} / \mu \mathrm{l})$ & $0.2 \mu \mathrm{l}$ \\
$\mathrm{dH} 2 \mathrm{O}$ & up to $25 \mu \mathrm{l}$ \\
\hline
\end{tabular}

\section{Thermocycling profile PCR}

PCR amplification was performed in a Perkin-Elmer/ GeneAmp ${ }^{\circledR}$ PCR System 9700 (PE Applied Biosystems) programmed to fulfill 35 cycles after an initial denaturation cycle for $5 \mathrm{~min}$ at $94{ }^{\circ} \mathrm{C}$. Each cycle consisted of a denaturation step at $94{ }^{\circ} \mathrm{C}$ for $45 \mathrm{~s}$, an annealing step at $46^{\circ} \mathrm{C}$ for $50 \mathrm{~s}$, and an elongation step at $72^{\circ} \mathrm{C}$ for $1 \mathrm{~min}$. The primer extension segment was extended to $7 \mathrm{~min}$ at $72{ }^{\circ} \mathrm{C}$ in the final cycle.

\section{Detection of the PCR products}

The amplification products were resolved by electrophoresis in a $1.5 \%$ agarose gel containing ethidium bromide $(0.5 \mathrm{ug} / \mathrm{ml})$ in $1 \mathrm{X}$ TBE buffer at $95 \mathrm{~V}$.

\section{Data handling and cluster analysis (Phylogenetic tree)}

Data were scored for computer analysis on the basis of the presence or absence of the amplified products for each primer. Pairwise components of the eight sugar beet accessions based on the presence or absence of unique and shared polymorphic products, were used to determine similarity coefficients according to Jaccard (1908). The similarity coefficients were then used to construct dendrograms, using the unweighted pair group method with arithmetic averages (UPGMA) employing the SAHN (Sequential, Agglomerative, Hierarchical and Nested clustering) from the NTSYS-PC (Numerical Taxonomy and Multivariate Analysis System), version 1.80 (Applied Biostatistics Program).

\section{Results}

\section{Analysis of variance (ANOVA Test)}

Results viewed in Table 3 and associated with analysis of variance test showed highly significant differences between the eight sugar beet genotypes for the 
Table 3 Mean squares for all studied traits of the eight sugar beet accessions in the two growing seasons (2017/2018 and 2018/2019)

\begin{tabular}{lcccccccc}
\hline S.O.V & D.F & Seasons & TSS \% & Sucrose $\%$ & Apparent purity \% & $\begin{array}{l}\text { Root yield } \\
\text { (Ton/Fed) }\end{array}$ & $\begin{array}{l}\text { Top yield } \\
\text { (Ton/Fed) }\end{array}$ & $\begin{array}{l}\text { Sugar yield } \\
\text { (Ton/Fed) }\end{array}$ \\
\hline Genotypes & 7 & $2017 / 2018$ & $19.35^{* *}$ & $8.56^{* *}$ & $14.38^{* *}$ & $21.59^{* *}$ & $31.87^{* *}$ & $6.48^{* *}$ \\
& & $2018 / 2019$ & $16.85^{* *}$ & $12.72^{* *}$ & $10.63^{* *}$ & $23.78^{* *}$ & $19.05^{* *}$ & $9.31^{* *}$ \\
Replicates & 2 & $2017 / 2018$ & $48.55^{* *}$ & $25.12^{* *}$ & $20.08^{* *}$ & $17.84^{* *}$ & $15.92^{* *}$ & $33.76^{* *}$ \\
& & $2018 / 2019$ & $34.90^{* *}$ & $18.39^{* *}$ & $27.47^{* *}$ & $15.03^{* *}$ & $22.72^{* *}$ & $28.56^{* *}$ \\
Error & 14 & $2017 / 2018$ & $\mathbf{1 . 2 9}$ & $\mathbf{2 . 0 5}$ & $\mathbf{0 . 9 5}$ & $\mathbf{1 . 2 1}$ & $\mathbf{1 . 7 3}$ & $\mathbf{1 . 5 5}$ \\
& & $2018 / 2019$ & $\mathbf{1 . 1 4}$ & $\mathbf{2 . 1 6}$ & $\mathbf{1 . 0 3}$ & 4.35 & $\mathbf{1 . 4 2}$ & $\mathbf{1 . 3 2}$ \\
C.V. \% & $2017 / 2018$ & 5.63 & 7.41 & 1.01 & 4.23 & 9.33 & 25.66 \\
& & $2018 / 2019$ & 5.31 & 7.66 & 1.06 & 23.73 &
\end{tabular}

Bold values are very important values that are used in the case of important comparisons in the results and discussion parts

six attributes under study during the two growing seasons (2017/2018 and 2018/2019). Coefficient of variance percentage was very low in apparent purity \% trait (1.01 and 1.06), medium in the traits; TSS\% (5.63 and 5.31), sucrose \% (7.41 and 7.66) and root yield (4.35 and 4.23) for the two seasons, while it was high in the traits; top yield (10.11 and 9.33) and sugar yield (25.66 and 23.73) for both growing seasons, respectively.

\section{Mean performance}

The mean values of all studied attributes for both growing seasons (2017/2018 and 2018/2019) were presented in Table 4 and Fig. 2. For TSS \% trait, the sugar beet cultivar Oscar Boly recorded the highest mean values in both seasons (21.79\% and $21.85 \%)$, followed by Rass poly (21.64\% and $21.89 \%$ ), followed by Mont Bianco (20.41\% and 20.15\%), followed by B2001 (20.05\% and 20. 02\%), followed by Blino (19.63\% and 19.74\%), followed by Baraca (19.67\% and 19.54\%), followed by Pita poly terry (19.68\% and 19.29\%) and then followed by Sultan (18.55\% and $18.19 \%$ ) for the two growing seasons, respectively. With respect to sucrose \% trait, the genotype Oscar Boly was exhibited the highest trend in this regard for both seasons (20.95\% and $20.74 \%$ ), followed by Rass poly (20.71\% and 20.49\%), followed by Mont Bianco (19.82\% and 19.65\%), followed by B2001 (19.36\% and 19.42\%), followed by Pita poly terry (18.79\% and $18.43 \%)$, followed by Baraca (18.55\% and $18.46 \%$ ), followed by Blino (18.37\% and 18.54\%) and then followed by Sultan (17.89\% and $17.68 \%$ ) for both growing seasons, respectively. In the same context, the sugar beet accession Mont Bianco exhibited the highest mean values for Apparent purity \% trait in both growing seasons $(97.10 \%$ and $97.51 \%)$, followed by Sultan (96.44\% and 97.19\%), followed by B2001 (96.55\% and $97.0 \%)$, followed by Oscar Boly $(96.14 \%$ and 94.91\%), followed by Pita poly terry (95.47\% and $95.54 \%$ ), followed by Rass poly (95.70\% and $93.60 \%$ ), followed by Baraca (94.30\% and $94.47 \%$ ) and then followed by Blino $(93.58 \%$ and $93.87 \%)$ for the two seasons, respectively.
Regarding root yield trait, the sugar beet genotype Blino was exhibited the first rank for both seasons (29.12 and $28.75 \mathrm{ton} / \mathrm{fed}$ ), followed by Sultan (28.23 and $27.84 \mathrm{ton} /$ fed), followed by Rass poly (27.52 and 27.52 ton/fed), followed by Baraca (26.08 and 25.86 ton/fed), followed by Oscar Boly (25.04 and 25.49 ton/fen), followed by Pita poly terry ( 24.20 and 24.59 ton/fed), followed by B2001 (22.19 and 23.07 ton/fed) and then followed by Mont Bianco (19.46 and 19.46 ton/fed) in both seasons, respectively. With respect to Top yield trait, the cultivar sultan was recorded the highest mean values in this regard for both season and the values were (17.09 and 16.65 ton/ fed), followed by Blino (15.19 and 12.97 ton/fed), followed by B2001 (14.39 and 13.72 ton/fed), followed by Pita poly terry (13.84 and 14.07 ton/fed), followed by Oscar Boly (11.82 and 11.82 ton/fed), followed by Baraca (12.09 and 12.24 ton/fed), followed by Mont Bianco (10.03 and 10.03 ton/fed) and then followed by Rass poly (9.62 and 10.02 ton/fed) for the two growing seasons, respectively. Concerning sugar yield trait, the sugar beet cultivar Rass poly was exhibited the highest mean values of this trait for both years (5.69 and 5.51 ton/fed), followed by Blino ( 5.34 and 5.32 ton/fed), followed by Oscar Boly ( 5.24 and 5.28 ton/fed), followed by Sultan ( 5.05 and 4.92 ton/fed), followed by B (4.83 and 4.77 ton/fed), followed by Pita poly terry ( 4.54 and 4.53 ton/fed), followed by B2001 (4.29 and 4.48 ton/fed) and then followed by Mont Bianco (3.85 and 3.93 ton/fed) for the two growing seasons, respectively, in Table 4.

\section{Genetic components}

Data presented in Table 5 showed that the values of heritability in broad sense were appeared high in the studied attributes; TSS \% (82.35\% and $82.10 \%)$, apparent purity $\%(82.47 \%$ and $75.65 \%)$, root yield $(84.87 \%$ and $86.76 \%)$ and top yield $(85.30 \%$ and $80.52 \%)$ in both growing seasons, respectively, while they were appeared medium in the traits; sucrose \% (51.42\% and 61.97\%) and sugar yield $(51.41 \%$ and $66.83 \%)$ in both years, respectively. In 
Table 4 Mean Performance and Combined Analysis for All Studied Traits of the eight sugar beet accessions in the two growing seasons (2017/2018 and 2018/2019)

\begin{tabular}{|c|c|c|c|c|c|c|c|c|c|}
\hline \multirow[t]{3}{*}{ Genotypes } & \multicolumn{9}{|l|}{ Traits } \\
\hline & \multicolumn{3}{|l|}{ TSS \% } & \multicolumn{3}{|l|}{ Sucrose $\%$} & \multicolumn{3}{|c|}{ Apparent purity $\%$} \\
\hline & $2017 / 2018$ & $2018 / 2019$ & Mean & $2017 / 2018$ & $2018 / 2019$ & Mean & $2017 / 2018$ & $2018 / 2019$ & Mean \\
\hline Baraca & 19.67 & 19.54 & 19.6 & 18.55 & 18.46 & 18.50 & 94.30 & 94.47 & 94.38 \\
\hline B2001 & 20.05 & 20.02 & 20.03 & 19.36 & 19.42 & 19.39 & 96.55 & 97.0 & 96.77 \\
\hline Sultan & 18.55 & 18.19 & 18.37 & 17.89 & 17.68 & 17.78 & 96.44 & 97.19 & 96.81 \\
\hline Mont Bianco & 20.41 & 20.15 & 20.28 & 19.82 & 19.65 & 19.73 & 97.10 & 97.51 & 97.30 \\
\hline Oscar Boly & 21.79 & 21.85 & 21.82 & 20.95 & 20.74 & 20.84 & 96.14 & 94.91 & 95.52 \\
\hline Blino & 19.63 & 19.74 & 19.68 & 18.37 & 18.53 & 18.45 & 93.58 & 93.87 & 93.72 \\
\hline Rass poly & 21.64 & 21.89 & 21.76 & 20.71 & 20.49 & 20.60 & 95.70 & 93.60 & 94.65 \\
\hline Pita poly terry & 19.68 & 19.29 & 19.48 & 18.79 & 18.43 & 18.61 & 95.47 & 95.54 & 95.50 \\
\hline Mean & 20.17 & 20.08 & 20.12 & 19.30 & 19.17 & 19.23 & 95.66 & 95.51 & 95.58 \\
\hline LSD at $5 \%$ & 1.58 & 1.49 & 1.53 & 1.99 & 2.05 & 2.02 & 1.35 & 1.41 & 1.38 \\
\hline LSD at $1 \%$ & 2.31 & 2.17 & 2.24 & 2.90 & 2.99 & 2.94 & 1.97 & 2.06 & 2.01 \\
\hline \multirow[t]{3}{*}{ Genotypes } & \multicolumn{9}{|l|}{ Traits } \\
\hline & \multicolumn{3}{|c|}{ Root yield (Ton/Fed) } & \multicolumn{3}{|c|}{ Top yield (Ton/Fed) } & \multicolumn{3}{|c|}{ Sugar yield (Ton/Fed) } \\
\hline & $2017 / 2018$ & $2018 / 2019$ & Mean & $2017 / 2018$ & $2018 / 2019$ & Mean & $2017 / 2018$ & $2018 / 2019$ & Mean \\
\hline Baraca & 26.08 & 25.86 & 25.97 & 12.09 & 12.24 & 12.16 & 4.83 & 4.77 & 4.80 \\
\hline B2001 & 22.19 & 23.07 & 22.63 & 14.39 & 13.72 & 14.05 & 4.29 & 4.48 & 4.38 \\
\hline Sultan & 28.23 & 27.84 & 28.03 & 17.09 & 16.65 & 16.87 & 5.05 & 4.92 & 4.98 \\
\hline Mont Bianco & 19.46 & 20.03 & 19.74 & 10.03 & 9.96 & 9.99 & 3.85 & 3.93 & 3.89 \\
\hline Oscar Boly & 25.04 & 25.49 & 25.26 & 11.82 & 12.52 & 12.17 & 5.24 & 5.28 & 5.26 \\
\hline Blino & 29.12 & 28.75 & 28.93 & 15.19 & 12.97 & 14.08 & 5.34 & 5.32 & 5.33 \\
\hline Rass poly & 27.52 & 26.91 & 27.21 & 9.62 & 10.02 & 9.82 & 5.69 & 5.51 & 5.60 \\
\hline Pita poly terry & 24.20 & 24.59 & 24.39 & 13.84 & 14.07 & 13.95 & 4.54 & 4.53 & 4.53 \\
\hline Mean & 25.23 & 25.31 & 25.27 & 13.0 & 12.76 & 12.88 & 4.85 & 4.84 & 4.84 \\
\hline LSD at $5 \%$ & 1.53 & 1.49 & 1.51 & 1.83 & 1.66 & 1.74 & 1.73 & 1.60 & 1.66 \\
\hline LSD at $1 \%$ & 2.23 & 2.18 & 2.20 & 2.67 & 2.42 & 2.54 & 2.53 & 2.33 & 2.43 \\
\hline
\end{tabular}

generally, it is natural that there are differences between PCV and GCV values for all the studied traits during the two years of the study because these differences are very importance and confirm beyond any doubt that the genetic variance occupied the greatest part of the total level of phenotypic variance when these differences being little and this is strongly reflected in the weakness of the environmental variance. In the same context, it is attributed to the growing values of the degree of heritability in the broad sense especially for yield and its components of sugar beet. On the other hand, vice versa if the differences between them are great.

In this investigation, the values of genotypic variance were higher than the values of environmental variance in all studied traits for the two growing seasons. Therefore, the major part of the phenotypic variance was the share of the genetic variance. In the same regard, the estimated values of PCV \% were bigger than its peers of GCV \% in all studied traits for the two seasons, where the values of PCV \% were high in the traits; sugar yield $(36.82 \%$ and $41.21 \%)$, followed by top yield ( $26.39 \%$ and $21.15 \%)$, followed by TSS $\%$ (13.40\% and $12.56 \%)$, followed by root yield (11.21\% and $11.64 \%)$, followed by sucrose $\%(10.64 \%$ and $12.43 \%)$ and then followed by apparent purity \% $(2.43 \%$ and $2.15 \%)$ in both growing seasons, respectively. In the same context, the differences between phenotypic and genotypic coefficient of variation $\left(D^{Z}\right)$ were low in all studied traits in both years except sugar yield trait where it recorded (10.42 and 7.52) in the two growing seasons, respectively. As was briefly explained earlier, the values of $\mathrm{D}^{\mathrm{z}}$ represent the final criterion for the differences between PCV and GCV \%. If these differences are large, this will reduce the values of the degree of heritability due to the presence of a large role for environmental variance. But, if it is small, which is the desired case, this confirms the large degrees of heritability in broad sense for 


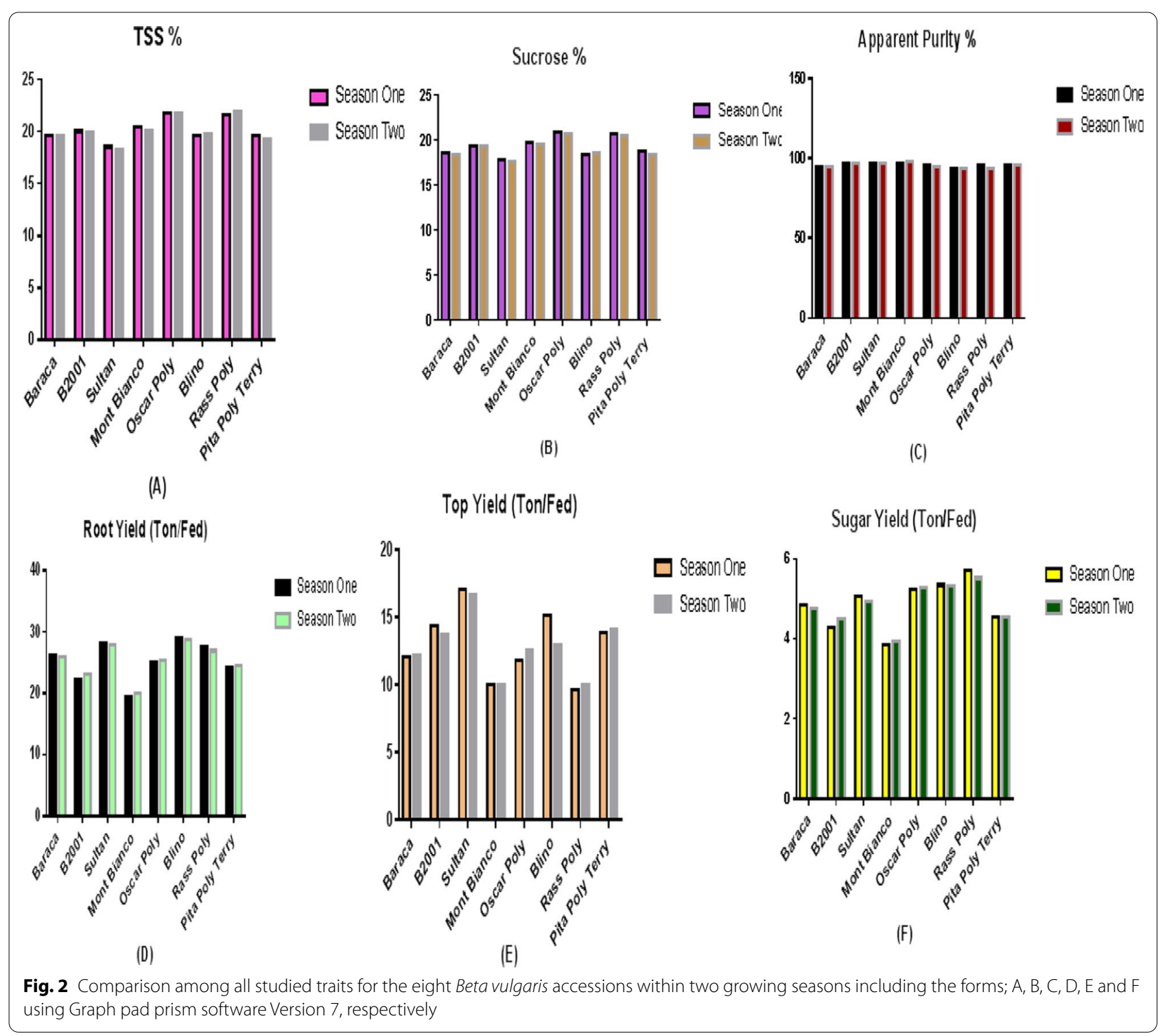

all quantitative traits. In addition, the absence of the role of the environment in changing the nature and shape of all attributes under study. Data assessment of expected genetic advance (GA) based on 5\% selection revealed various results for all studied traits in both growing seasons, where it was medium in the traits; TSS \% (4.60\% and $10.81 \%)$, root yield (4.96\% and 5.28\%) and top yield $(6.05 \%$ and $12.13 \%)$ and appeared low in the rest traits, namely sucrose \% (2.18\% and $3.05 \%)$, apparent purity \% (3.97\% and $3.21 \%$ ) and sugar yield (1.89\% and $2.75 \%)$, respectively. It is worth mentioning that genetic advance is one of the most important genetic measurements that are used to know the extent and size of change in the performance of important quantitative traits such as resistance to biotic and abiotic stresses. As well as, strategic yield traits, especially sugar attributes in this regard and their reach to a positive direction, which in turn is reflected in the final yield for plant breeders, as well as for both the farmer and the consumer. Accordingly, the aim of using it in this study is to find out to what extent these imported sugar beet genotypes have reached the genetic stability in yield and its components and to ensure its high performance under the Egyptian environment conditions. This is what makes it more important in this context. With respect to GAM \%, the first rank of this genetic parameter was observed in top yield trait $(46.53 \%$ and $95.06 \%)$, followed by sugar yield trait $(38.96 \%$ and $56.81 \%)$, followed by TSS \% trait (22.80\% and $53.83 \%)$, followed by root yield trait (19.65\% and $20.86 \%$ ), followed by sucrose \% trait (11.29\% and $15.91 \%)$ and then followed 


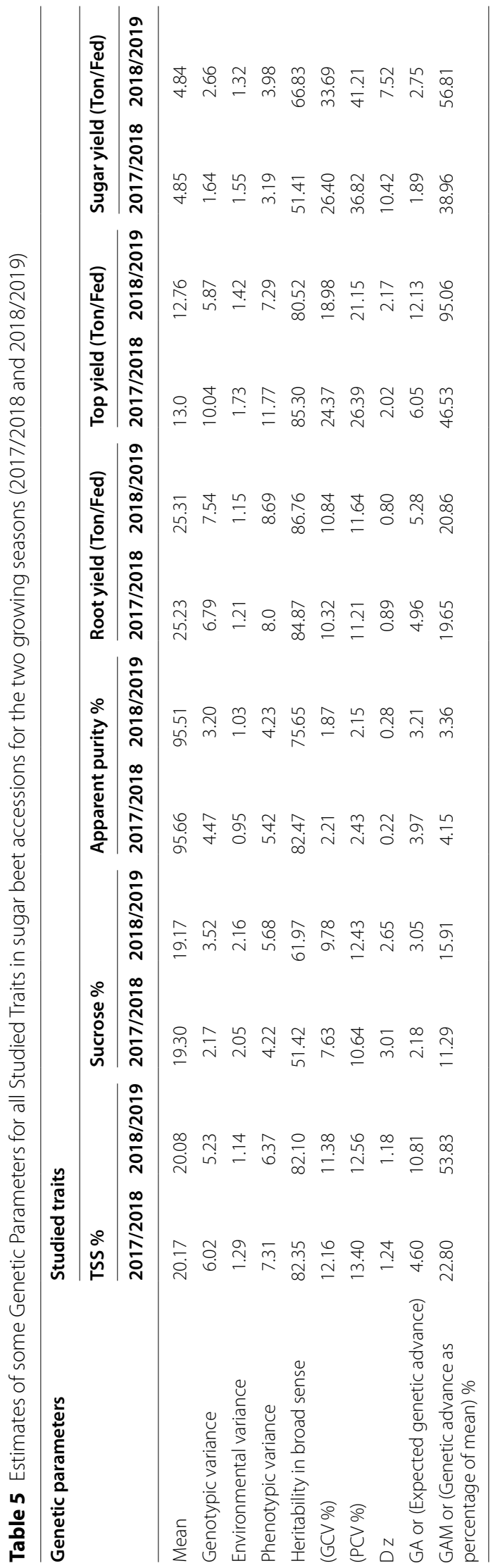


by apparent purity $\%$ trait $(4.15 \%$ and $3.36 \%)$ for the two growing seasons, respectively.

\section{Molecular characterization Profile of ISSR analysis}

The twelve ISSR primers used for comparing among the eight sugar beet accessions, namely ISSR-1, 2, 3, 4, 5, 6, $7,8,9,10,11$ and 13 exhibited a total of 169 fragments, 47 of them were monomorphic, while that, 122 bands were showed polymorphic with $72.18 \%$ (polymorphism) included 15 unique bands as presented in Table 6; Fig. 3. The average numbers of polymorphic ISSR markers were 10.16 fragments for each primer. Polymorphic bands number ranged from 6 to 17 and molecular size ranging from 140 to $1450 \mathrm{bp}$, respectively. The highest number of total bands was observed by primer ISSR-1 (22), followed by ISSR-2 primer (20), followed by the primers; ISSR-3 and 6 (17) fragment for both of them, followed by ISSR-4 primer (15), followed by ISSR-7 (14), followed by ISSR-10 primer (12), followed by the primers; ISSR-8 and 9 (11) bands for both of them and then followed by the primers; ISSR-5, 11 and 13 (10) fragments for them all, respectively. Further, the highest number of polymorphic bands were showed in primer ISSR-1 (17), followed by the primers ISSR-2, 3 and 6 (13) for them all, followed by ISSR-7 primer (11), followed by ISSR-11 (9), followed by the primers; ISSR 8 and 9 where they recorded 8 bands for both of them and then followed by the primers; ISSR- 5 and 10 (7) fragments for both of them, respectively, while ISSR-13 primer was exhibited the lowest number of polymorphic bands (6). In the same context, the highest polymorphism \% were observed in primers; ISSR-11 (90.0\%), followed by ISSR-7 (78.57\%), followed by ISSR-1 (77.27\%), followed by ISSR-3 and 6 (76.47\%) for both of them, followed by ISSR-8 and 9 (72.72\%) for together, followed by ISSR-5 (70.0\%), followed by ISSR-4 (66.66\%), followed by ISSR-2 (65.0\%), followed by ISSR-13 (60.0\%) and then followed by the primer ISSR-10 (58.33\%) where it recorded the lowest polymorphism \% in this regard, respectively. Further, primers; ISSR-6, 3 and 5 recorded the highest number of unique bands where they exhibited (4, 3 and 2) bands for them of all, respectively. In addition, the rest primers generated only unique band except the three primers; ISSR-4, 10 and 13 where they exhibited no unique band in this investigation.

Data viewed in Table 7 detected that the sugar beet cultivars B2001, Mont Bianco, Oscar Boly and Pita poly terry recorded the highest number of amplified fragments and were coming in the first rank in this regard and their values were (102, 103, 109 and 96), respectively. The other sugar beet genotypes coming in the second rank showed different number of bands. Further, primers ISSR-1, 2, 4 and 6 exhibited the highest number of bands $(94,102,73$ and 72$)$ for each one of them in all sugar beet genotypes, while ISSR-5, 8 and 11 primers generated the lowest number of amplicons (45, 46 and 41) for all of them, respectively. In addition, the rest ISSR primers were exhibited various number of amplified fragments.

Data viewed in Table 8 showed 15 positive specific markers generated by twelve ISSR primers. These primers, namely ISSR-1, 2, 3, 4, 5, 6, 7, 8, 9, 10, 11 and 13, used in the current study succeeded in discovering and comparing the molecular genetic differences among the different sugar beet genotypes Table 8 . In addition, these molecular genetic differences were very important in this regard, especially since the eight sugar beet accessions came from different environmental origins and regions. As well, these molecular genetic differences are considered basic taxonomic differences among the eight sugar beet accessions. The following is a detailed explanation

Table 6 Band variation and polymorphism percentage in 8 sugar beet genotypes using 12 ISSR primers

\begin{tabular}{|c|c|c|c|c|c|c|c|}
\hline No & ISSR primers & T.S & M.B & P.B & U.B or P.S.M & $\mathrm{P} \%$ & R.S \\
\hline 1 & ISSR-1 & 22 & 5 & 17 & 1 & 77.27 & $150-1250$ \\
\hline 2 & ISSR-2 & 20 & 7 & 13 & 1 & 65.0 & $250-1450$ \\
\hline 3 & ISSR-3 & 17 & 4 & 13 & 3 & 76.47 & $160-1250$ \\
\hline 4 & ISSR-4 & 15 & 5 & 10 & 0 & 66.66 & $160-760$ \\
\hline 5 & ISSR-5 & 10 & 3 & 7 & 2 & 70.0 & $160-1000$ \\
\hline 6 & ISSR-6 & 17 & 4 & 13 & 4 & 76.47 & $140-1300$ \\
\hline 7 & ISSR-7 & 14 & 3 & 11 & 1 & 78.57 & $160-700$ \\
\hline 8 & ISSR-8 & 11 & 3 & 8 & 1 & 72.72 & $140-920$ \\
\hline 9 & ISSR-9 & 11 & 3 & 8 & 1 & 72.72 & $160-620$ \\
\hline 10 & ISSR-10 & 12 & 5 & 7 & 0 & 58.33 & $147-965$ \\
\hline 11 & 1SSR-11 & 10 & 1 & 9 & 1 & 90.0 & $172-1000$ \\
\hline 12 & ISSR-13 & 10 & 4 & 6 & 0 & 60.0 & $150-1117$ \\
\hline Total & & 169 & 47 & 122 & 15 & 72.18 & $140-1450$ \\
\hline
\end{tabular}

Bold values are very important values that are used in the case of important comparisons in the results and discussion parts 


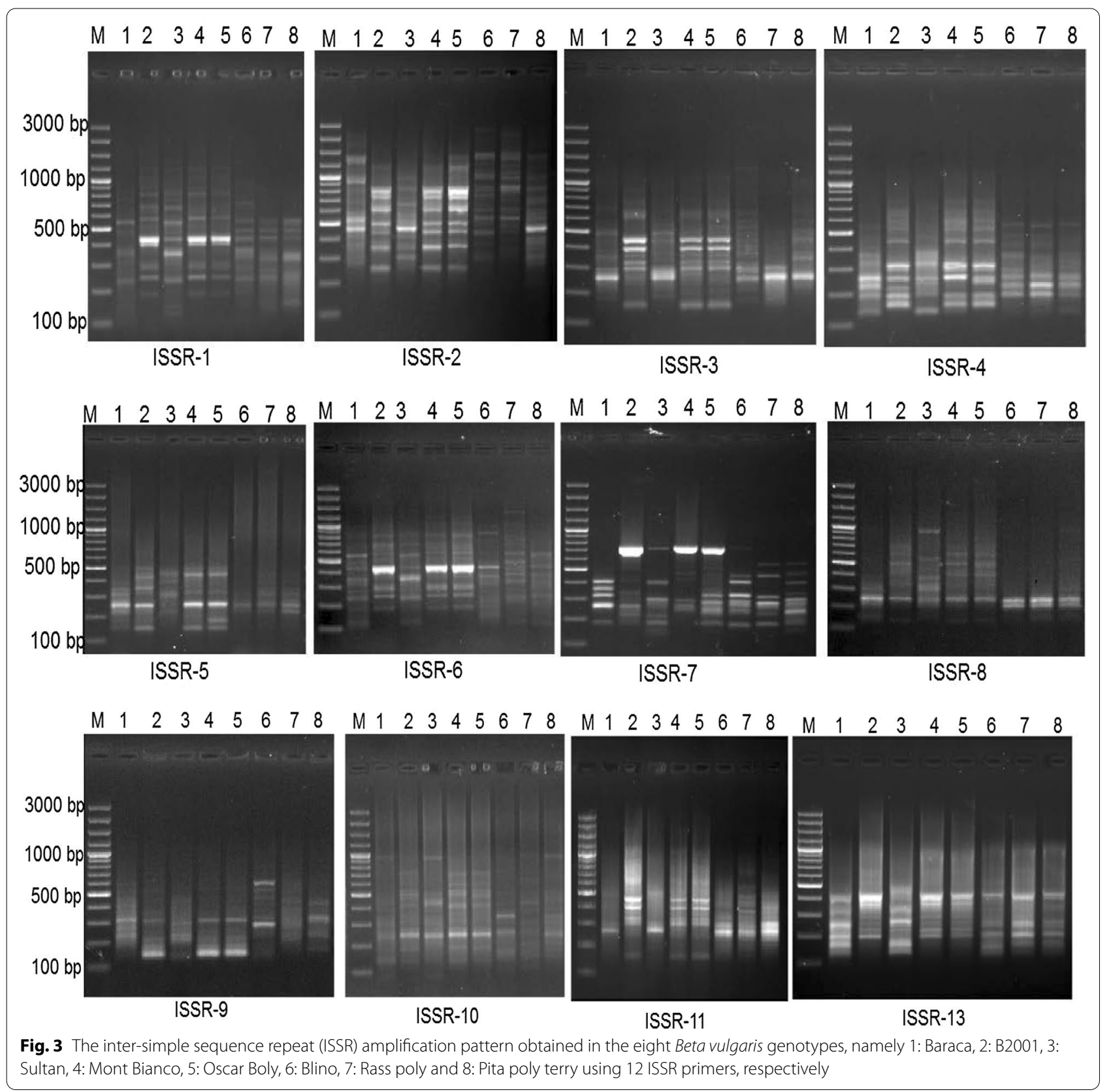

of ISSR primers that gave positive markers in this track. ISSR-1 and 2 primers exhibited 2 positive specific marker in sugar beet genotypes; 3 and 7 with sizes of 150 and $1100 \mathrm{bp}$, besides, three positive markers with sizes of 690, 810 and 1250 bp were obtained in genotypes; 1,2 and 6 by ISSR- 3 primer, respectively. For ISSR- 5 primer, two positive markers were observed in genotypes; 5 and 7 with sizes of 190 and $1000 \mathrm{bp}$. With respect to ISSR-6 primer, four positive specific markers were observed in this regard as follows; two markers with sizes of 1200 and 170 bp for genotypes; 5 and 6 besides, two markers with sizes of 330 and $1300 \mathrm{bp}$ for genotype 7 only, respectively. In the same context, ISSR-7 and 8 primers produced two positive markers with sizes of 160 and 530 bp for genotype 3 only. Finally, ISSR- 9 and 11 primers exhibited two positive specific markers with sizes of 620 and $209 \mathrm{bp}$ for sugar beet genotypes; 6 and 8, respectively.

\section{Proximity matrix analysis (Genetic Similarity)}

Data presented in Table 9 exhibited (28) pairwise comparisons to debate the genetic relationships between the eight sugar beet genotypes revealed in terms of genetic 
Table 7 Total bands obtained from the twelve ISSR primers of the eight sugar beet accessions and all amplified fragments for each genotype

\begin{tabular}{|c|c|c|c|c|c|c|c|c|c|c|c|c|c|}
\hline \multirow[t]{2}{*}{ Genotypes } & \multicolumn{13}{|l|}{ Primers } \\
\hline & ISSR-1 & ISSR-2 & ISSR-3 & ISSR-4 & ISSR-5 & ISSR-6 & ISSR-7 & ISSR-8 & ISSR-9 & ISSR-10 & ISSR-11 & ISSR-13 & Total \\
\hline Baraca & 11 & 11 & 7 & 8 & 6 & 10 & 6 & 5 & 6 & 5 & 3 & 8 & 86 \\
\hline B2001 & 12 & 13 & 10 & 11 & 7 & 8 & 6 & 6 & 6 & 10 & 7 & 6 & 102 \\
\hline Sultan & 14 & 11 & 7 & 7 & 5 & 7 & 8 & 7 & 7 & 5 & 2 & 9 & 89 \\
\hline Mont Bianco & 11 & 12 & 12 & 10 & 6 & 8 & 8 & 7 & 6 & 10 & 7 & 6 & 103 \\
\hline Oscar Boly & 10 & 14 & 12 & 10 & 7 & 10 & 8 & 7 & 7 & 10 & 8 & 6 & 109 \\
\hline Blino & 14 & 13 & 8 & 10 & 2 & 10 & 8 & 4 & 7 & 7 & 3 & 5 & 91 \\
\hline Rass poly & 11 & 14 & 4 & 8 & 6 & 11 & 7 & 4 & 6 & 6 & 5 & 7 & 89 \\
\hline Pita poly terry & 11 & 14 & 8 & 9 & 6 & 8 & 8 & 6 & 5 & 8 & 6 & 7 & 96 \\
\hline Total bands & 94 & 102 & 68 & 73 & 45 & 72 & 59 & 46 & 50 & 61 & 41 & 54 & 765 \\
\hline
\end{tabular}

Table 8 Mapping of positive specific markers for the eight sugar beet genotypes using 12 ISSR primers

\begin{tabular}{|c|c|c|c|c|c|c|c|c|c|c|}
\hline ISSR primers & MS(bp) & G1 & G2 & G3 & G4 & G5 & G6 & G7 & G8 & Positive Marker \\
\hline ISSR-1 & 150 & - & - & + & - & - & - & - & - & $P(G 3)$ \\
\hline ISSR-2 & 1100 & - & - & - & - & - & - & + & - & $P(G 7)$ \\
\hline \multirow[t]{3}{*}{ ISSR-3 } & 1250 & - & - & - & - & - & + & - & - & $P(G 6)$ \\
\hline & 810 & - & + & - & - & - & - & - & - & $P(G 2)$ \\
\hline & 690 & + & - & - & - & - & - & - & - & $P(G 1)$ \\
\hline \multirow[t]{2}{*}{ ISSR-5 } & 1000 & - & - & - & - & - & - & + & - & $P(G 7)$ \\
\hline & 190 & - & - & - & - & + & - & - & - & $P(G 5)$ \\
\hline \multirow[t]{4}{*}{ ISSR-6 } & 1300 & - & - & - & - & - & - & + & - & $P(G 7)$ \\
\hline & 1200 & - & - & - & - & + & - & - & - & $P(G 5)$ \\
\hline & 330 & - & - & - & - & - & - & + & - & $P(G 7)$ \\
\hline & 170 & - & - & - & - & - & + & - & - & $P(G 6)$ \\
\hline ISSR-7 & 160 & - & - & + & - & - & - & - & - & $P(G 3)$ \\
\hline ISSR-8 & 530 & - & - & + & - & - & - & - & - & $P(G 3)$ \\
\hline ISSR-9 & 620 & - & - & - & - & - & + & - & - & $P(G 6)$ \\
\hline ISSR-11 & 209 & - & - & - & - & - & - & - & + & $P(G 8)$ \\
\hline Range & $1300-150$ & & & & & & & & & \\
\hline Total & & 1 & 1 & 3 & 0 & 1 & 2 & 2 & 1 & 15 (Positive markers) \\
\hline
\end{tabular}

Table 9 Genetic similarity \% in 8 sugar beet genotypes using 12 ISSR Primers

\begin{tabular}{llllllll}
\hline Genetic similarity & G1 & G2 & G3 & G4 & G5 & G6 & G7 \\
\hline G1 & 1.0 & & & & & & \\
G2 & 0.402 & 1.0 & & & & & \\
G3 & 0.635 & 0.446 & 1.0 & & & & \\
G4 & $\mathbf{0 . 4 0 0}$ & $\mathbf{0 . 8 6 3}$ & 0.432 & 1.0 & & & \\
G5 & 0.413 & $\mathbf{0 . 8 0 3}$ & 0.414 & $\mathbf{0 . 8 7 6}$ & 1.0 & & \\
G6 & 0.566 & 0.408 & 0.525 & 0.405 & 0.428 & 1.0 & 1.0 \\
G7 & 0.576 & 0.436 & 0.547 & 0.432 & 0.424 & 0.592 & 0.681 \\
G8 & 0.625 & 0.445 & 0.651 & 0.452 & 0.464 & 0.598 & 1.0 \\
\hline
\end{tabular}

Bold values are very important values that are used in the case of important comparisons in the results and discussion parts 
similarity. The genetic similarity values ranged from (0.876 to 0.400$)$ with an average of $(0.638)$, where the highest level of genetic similarity was (0.876) among (Genotype 4 and Genotype 5). While that, the lowest rank of similarity was (0.400) between (Genotype 1 and Genotype 4), respectively. Further, some genetic similarity values were showed a little above average such as the genetic relationships among (Genotype 1 and Genotype 8) (0.625), (Genotype 3 and Genotype 8) (0.651) and (Genotype 7 and Genotype 8) (0.681), respectively. The rest genetic similarity values were appeared low to medium in this regard.

\section{Cluster analysis (Phylogenetic tree)}

Results of cluster analysis or phylogenetic tree which presented in Fig. 4 divided all sugar beet genotypes into two main clusters, where the cluster I included genotypes; 2 , 4 and 5, while cluster II contained genotype 6 and two sub-cluster. The sub-cluster one included one group (genotype 1 and genotype 3 ). Whatever, the sub-cluster number two included one group (genotype 7 and genotype 8 ), respectively.

\section{Discussion}

The scientific facts shown in Table 3 confirmed that the environmental variation had a very weak effect in inheriting the recent traits and that genetics played a pivotal and essential role for manufacturing highly genetic stability in these genetic materials of sugar beet. Further, this results were verified through evaluating all studied traits during two growing seasons. In addition, the great genetic diversity shown by these sugar beet accessions confirms that its use in breeding and improvement programs of sugar beet under Egyptian conditions will be a very important step in this context. These results were in agreement with those reported by Izadi-Darbandi et al. (2013), Andrello

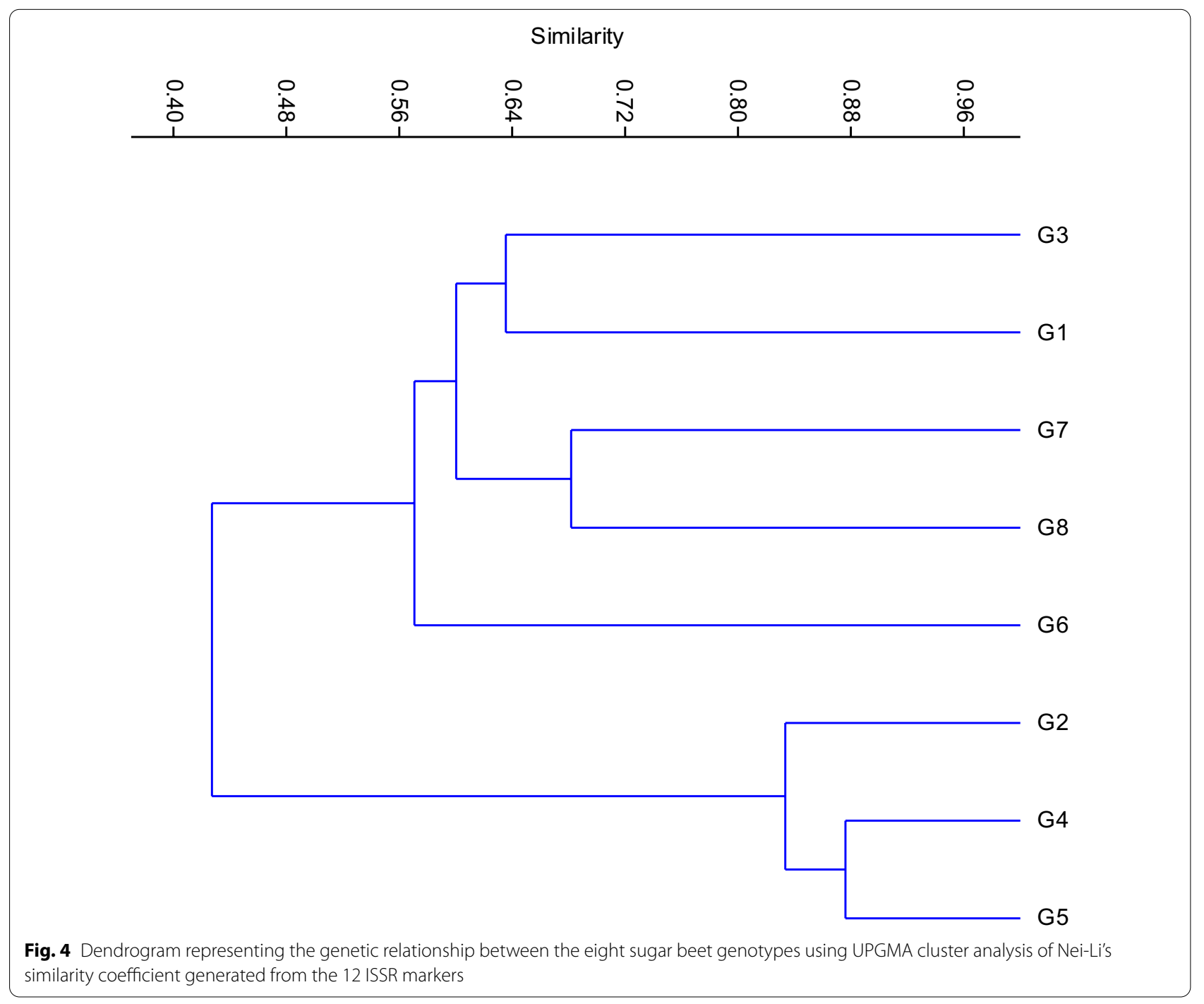


et al. (2016), Taski-Ajdukovic et al. (2017), Galewski and Mcgrath (2020), El-Mouhamady and El-Metwally (2020) and Bassiony et al. (2020).

Results obtained in Table 4 and Fig. 2 confirm the existence of a large genetic diversity between the eight sugar beet accessions under evaluating. This fact was confirmed by observing all values and data for all studied characteristics of these genetic materials during the two growing seasons, where some varieties surpassed in certain traits, while the rest of sugar beet cultivars were excelled in the rest of the other attributes. In the context, the sugar beet cultivar Oscar Boly was recorded the highest rank in the traits; TSS \% and sucrose \% during both growing seasons, while the cultivar Mont Bianco exhibited the first rank in apparent purity \% trait and the genotype Blino was shown highly data in root yield trait. Furthermore, the accessions, Sultan and Rass Boly, were recorded the highest rank for the traits; Top yield and sugar yield for the two growing seasons, respectively. For the rest of sugar beet varieties, it came in second place in terms of excellence of all studied traits. In addition, these varieties have already succeeded in environmental adaptation and genetic stability under Egyptian conditions. Accordingly, the use of sugar beet accessions that are genetically diverse and various origin had the greatest credit for the genetic improvement in all attributes under investigating, especially for each of sugar yield and root yield. Therefore, its inclusion in programs to improve and develop the characteristics of the sugar beet crop in Egypt will be a very important decision and a serious scientific step that has an economic impact in the long run. This will definitely reduce the big gap between white sugar production and consumption in Egypt. These results were in agreement with those obtained by Izadi-Darbandi et al. (2013), ElMouhamady et al. (2014a, 2014b), Abbasi et al. (2014), Ganapati et al. (2015), Taski-Ajdukovic et al. (2017), Baloch (2017), Putnik-Delić et al. (2018), Monteiro et al. (2018), ARESC (2019), Galewski and Mcgrath (2020) and El-Mouhamady and El-Metwally (2020).

Results viewed in Table 5 revealed that in the case of heritability in broad sense was high in the traits; TSS $\%$, apparent purity \%, root yield and top yield for both growing seasons indicates that the genetic variation was a great influence for controlling in the inheriting of these previous traits, while the role and influence of environmental variation diminished. Whatever, in the case of heritability was medium in the studied traits; sucrose $\%$ and sugar yield in both years confirms that confirms that the genetic and environmental variation were equal in terms of influence and control in the inheritance of these two traits (El-Mouhamady 2009; El-Demardash et al. 2017; Singh et al. 2018; ElMouhamady and El-Metwally 2020). Moreover, it was observed from the context of these results that the largest part of the total variance was from the share of the genetic variation in all the studied traits during both growing seasons. This indicates the basic, pivotal and important role of genetic variation in controlling and inheriting of all traits under studying. Besides, it confirms that the role of environmental variation has diminished in most studied traits. Therefore, breeding these traits using these different sugar beet genotypes with various origin in order to raise sugar and root yield in Egypt will be an inevitable and necessary matter at this time (Izadi-Darbandi et al. 2013; El-Mouhamady et al. 2014a, 2014b; Abbasi et al. 2014; Ganapati et al. 2015; Taski-Ajdukovic et al. 2017; ElMouhamady and Habouh 2019; Galewski and Mcgrath 2020; El-Mouhamady and El-Metwally 2020). Through results obtained in Table 5, it was noted that the PCV \% values of all tested traits were greater than their counterparts in GCV \% during both growing seasons. This explains that the genetic improvement of these traits was not dependent on the genotype only, but on the environment and the interaction between environmental X genotype. Thus, selection processes for development of all studied traits mentioned above through phenotype could be the fruitful goal in this direction. This greatly demonstrated the extent of the genetic stability that these genotypes enjoy. These results were in agreement with those reported by Eldessouky et al. (2016), Al-Kordy et al. (2019), Tawfik and El-Mouhamady (2019), El-Mouhamady and Ibrahim (2020) and ElMouhamady and El-Metwally (2020).

In the same context, Singh et al. (2018) confirmed that studied traits with higher values of GCV, PCV and heritability in sugar beet related with better genetic advance and highly significant positively a complication with root yield and heaving high direct and indirect impacts are considering as selection criteria while selection to be made for higher sugar and sugar yield evaluated of genetic variability.

Values of expected genetic advance (GA) based on 5\% selection for all studied traits in both years appeared low to medium confirmed that additive and non-additive types of gene action were played an importance and fruitful role for controlling and inheriting the previous traits. Thus, the simple selection process for these traits would be effective through individual plants, while calculated data of GAM \% (Genetic advance as percentage of mean \%) for all attributes under investigating in both seasons pointed to the fruitful role of additive gene action responsible for controlling and inheriting the previous traits. These results were in agreement with those reported by Hamawaki et al. (2012), Abou El-Nasr et al. (2013), Shoaib et al. (2016), Chandrawat 
et al. (2017), El-Mouhamady et al. (2017), Tawfik and El-Mouhamady (2019), El-Mouhamady and El-Metwally (2020) and El-Mouhamady and Ibrahim (2020).

One of the most positive fruits of this study was the use of different genotypes of sugar beet origin. This means that the plant breeder has already seized an opportunity to select and choice the best genes that express useful quantitative traits that can be used to establish a successful breeding and improvement program for sugar beet. Because of, the eight sugar beet varieties had already shown a large trend of genetic variation and were various from each other, although all of them were superior in all of the estimated traits. This indicates that its genetic background is very large. Therefore, it can cover all the requirements of the process of genetic improvement and promotion of the sugar beet crop under Egyptian conditions. Moreover, the genetic parameters used in this context indicated impressive results for the degree of heritability in broad sense, as it was high in most calculated traits. This confirms that additive type of gene action act was very important for inheriting and controlling the previous traits and that using them in traditional breeding programs by hybridizing them among local sugar beet varieties will be a fruitful step in improving yield and roots attributes, and then the productivity and quality of white sugar.

The twelve ISSR primers used in this study were unrivaled success in finding the molecular genetic differences and determining the extent of genetic diversity between the eight sugar beet cultivars (Table 6; Fig. 3). Because of these genetic differences were considered as dividing taxonomic differences between the aforementioned sugar beet genotypes and identified 15 unique or positive specific markers generated from primers; ISSR-1, 2, 3, 5, 6, 7, 8, 9 and 11 in Table 8. Therefore, these unique markers manufactured the genetic identification at the molecular level among these sugar beet accessions in this regard, (El-Mouhamady et al. 2010, 2012a, 2013; Abdel Sattar and El-Mouhamady 2012; El-Seidy et al. 2013; Dohm et al. 2014; Esmail et al. 2016; Capistrano-Gossmann et al. 2017; Khatab et al. 2017; Khatab et al. 2019).

In this respect, ISSR markers had played an very importance and fruitful role to show the variability and genetic diversity which ranged from $58.33 \%$ by ISSR-10 primer to $90.0 \%$ using ISSR-11 primer and this technique was used in many studies such as in (Phaseolus vulgaris L.) by Galvan et al. (2003), in Artemisia capillaries by Shafie et al. (2009), in Lippia alba Mill by Manica-Cattani et al. (2009), in Achillea millefolium by Farajpour et al. (2012), in barley by El-Mouhamady et al. (2012b), in Lupine by Zian et al. (2013), in wheat by El-Mouhamady et al. (2014a, 2014b) and Heiba et al. (2016).
As well, this study was able to determine the total number of fragments resulting from each primer for each genotype besides, referred to the detailed molecular genetic comparison among these primers. For example, ISSR- 1 and 2 primers were exhibited the highest number of bands (94 and 102) for each of them in Table 7, respectively. In addition, screening the eight sugar beet varieties and knowing which is the largest in producing of amplicons like B2001 (102), Mont Bianco (103) and Oscar Boly (109). This has already participated in knowing the degrees of genetic diversity for these genotypes, especially as they are of different origin. These results were in agreement with those reported by Ganapati et al. (2015), Ramadan et al. (2016), Taski-Ajdukovic et al. (2017), ElMouhamady et al. (2019), Galewski and Mcgrath (2020), Abou-Elwafa et al. (2020) and El-Mouhamady et al. (2021).

Data viewed in Table 9 explained the genetic diversity with its two types, whether it was genetic affinity or divergence. This genetic compatibility or divergence helps the plant breeder to choose genetically compatible genotypes to a large extent and this reflects the environmental compatibility in establishing a successful breeding program in which genetic improvement is among its priorities by making use of the excellent genes present in the imported varieties and responsible for tolerating to high salinity, water stress and resistance diseases through hybridization and transfer these important genes by modern biotechnological methods to local genotypes. In the same context, the genetic similarity among the eight sugar beet accessions were observed between Mont Bianco and Oscar Poly (0.876), followed by B2001 and Mont Bianco (0.863) and then followed by B2001 and Oscar Poly (0.803). While that, the lowest genetic similarity was obtained among Baraca and Mont Bianco (0.400), respectively. These results, in short, explained the importance of genetic diversity and its ratio related to the extent of genetic divergence or convergence between the previously mentioned sugar beet varieties. This will facilitate its optimal use in the sugar beet breeding and improvement program under Egyptian conditions, especially as it is superior in all the traits under studying (ElMouhamady et al. 2012c, 2016; Galewski and Mcgrath 2020).

The phylogenetic tree or cluster analysis revealed in Fig. 4 divided all sugar beet genotypes into two main cluster, where cluster one included B2001, Mont Bianco and Oscar Poly, while cluster two contained the rest of sugar beet varieties. These results confirmed that the genotypes obtained in the first cluster were genetically different and divergent from those in the second cluster. This indicates that they are actually descended from genetic origins and a different environment, which maximizes 
the opportunity to benefit from those foreign genes in the genetic improvement of all studied traits and the improvement of sugar beet yield under conditions Egyptian (El-Mouhamady et al. 2015; Funk et al. 2018; AbouElwafa et al. 2020; Mehareb et al. 2021). It is worth noting that the three aforementioned local varieties; (Baraca, B2001 and Sultan) and which fall into the two major cluster are originally imported and cultivated under Egyptian environment before the other imported lines and this is gave them the local character. Accordingly, it was necessary to test its environmental adaptation with other imported varieties and to know the degree of its genetic diversity in the presence of the other five imported cultivars. In addition, the process of producing sugar beet is difficult in Egypt, as the Egyptian environmental conditions do not suitable for it. Therefore, the use of the eight genetic materials will be a great scientific leap in breeding and improvement Egyptian sugar beet program in this regard.

\section{Conclusion}

This study attempted with a bit of verbosity to shed light on the importance of sugar beet crop and to determine the degree of genetic variation for a number of genotypes coming from different origins through two growing seasons. Likewise, this study came as a natural response to the genetic improvement in sugar beet to increase white sugar productivity in Egypt and reduce the large gap between production and consumption. Further, the strategy of this work was evaluating a set of important yield attributes of sugar beet using 8 different genotypes with various origins and knowing the degree of their environmental adaptation. Besides, determining which of them is best for enriching the breeding and genetic improvement program in this important crop and that's after determining relationships of convergence and genetic divergence among them. Heritability in broad sense, PCV \%, GCV \%, $\mathrm{D}^{\mathrm{z}}$, GA (Expected genetic advance) and GAM (Genetic advance as percentage of mean \%) were the most important genetic parameters calculated for all studied attributes in both growing seasons. Twelve ISSR primers were used to compare among the eight sugar beet accessions and determine the genetic diversity among them at the molecular level. The final results indicated and confirmed that the eight sugar beet varieties were significantly different from each other. This indicates that the genetic diversity among them was remarkable and they were different in their genetic behavior. In the same regard, the sugar beet accessions; Oscar poly, Mont Bianco, Blino, Sultan and Rass Boly were recorded the highest mean values for all attributes under studying in both growing seasons. Further, this distinction qualifies them to be an important resource in the breeding and genetic improvement program for sugar beet in Egypt.

\begin{abstract}
Abbreviations
*: Significant at $5 \%$ probability level; **: Significant at $1 \%$ probability level; GCV \%: Genotypic coefficient of variance percentage; PCV \%: Phenotypic coefficient of variance percentage; $D^{z}$ : The difference between the phenotypic coefficient of variation (PCV \%), genotypic coefficient of variation (GCV\%); C.V\%: Coefficient of variance percentage; TSS \%: Total soluble solids in roots; A: Adenine; T: Thymine; G: Guanine; C: Cytosine; Y: (C or T), R (A or G); H: (A or C or T); G: Genotype; G1: Baraca; G2: B2001; G3: Sultan; G4: Mont Bianco; G5: Oscar Boly; G6: Blino; G7: Rass poly; G8: Pita poly terry; T.S: Total bands; M. B: Monomorphic band; P.B: Polymorphic band; U.B or P.S.M: Unique band or positive specific markers; P \%: Polymorphism percentage; R.S: Range size (bp); P: Positive; MS: Molecular size.
\end{abstract}

\section{Acknowledgements}

Not applicable.

\section{Authors' contributions}

ABAE done the part of plant breeding, statistical analysis, molecular markers and written the paper. MAA contributed to agriculture, statistical analysis and reviewed the final manuscript. TAE contributed to agriculture and reviewed the final manuscript. All authors read and approved the final manuscript.

\section{Funding}

Not applicable.

\section{Availability of data and material}

The datasets used and/or analyzed during the current study are available from the corresponding author on reasonable request.

\section{Declarations}

Ethics approval and consent to participate Not applicable.

\section{Consent for publication}

Not applicable.

\section{Competing interests}

The authors declare that they have no competing interests.

\section{Author details}

${ }^{1}$ Genetic Engineering and Biotechnology Research Division, Genetics and Cytology Department, National Research Centre, 33 El Buhouth ST., Dokki, Cairo 12622, Egypt. ${ }^{2}$ Agriculture and Biological Division, Field Crops Research Department, National Research Centre, 33 El Buhouth ST., Dokki, Giza 12622, Egypt.

Received: 15 April 2021 Accepted: 25 September 2021

Published online: 09 October 2021

\section{References}

Abbasi Z, Arzani A, Majidi MM (2014) Evaluation of genetic diversity of sugar beet (Beta vulgaris L.) crossing parents using agro-morphological traits and molecular markers. J Agric Sci Technol 16:1397-1411

Abdel Sattar AA, El-Mouhamady AA (2012) Genetic analysis and molecular markers for yield and its components traits in faba bean (Vicia Faba L.). Aust J Basic Appl Sci 6:458-466

Abou El-Nasr THS, Ibrahim MM, Aboud KA, El-Enany MAM (2013) Assessment of genetic variability for three coriander (Coriandrum sativum L.) cultivars grown in Egypt, using morphological characters essential oil composition and ISSR markers. World Appl Sci J 25:839-849

Abou-Elwafa SF, Abou El-Eyuoon AA, Eujayl I (2020) Genetic diversity under heat stress and deficit irrigation. Agron J 112:3579-3590 
Al-Kordy MA, Ibrahim HM, El-Mouhamady AA, Abdel-Rahman HM (2019) Genetic stability analysis and molecular depiction in elite entries of rice (Oryza sativa L.). Bull Natl Res Centre 43:1-15

Andrello M, Henry K, Devaux P, Desprez B, Manel S (2016) Taxonomic, spatial and adaptive genetic variation of Beta section Beta. Theor Appl Genet 129:257-271

Annual Report of Egyptian Sugar Crops Council (2019) 'Sugar crops and sugar production in Egypt in 2017/2018 growing and Juice 2019 season

Baloch A (2017) Genetic diversity analysis in commercial sugarcane (Saccharum officinarum L.) genotypes. Pak J Biotechnol 14:167-171

Bassiony ENA, Abdel Fatah M, Khadijah M, El-Gabry IM, Mehareb EM (2020) Yield performance and AMMI biplot analysis of some sugar beet varieties under olive mill waste treatments at multi environmental conditions. Direct Res J Agric Food Sci 8:48-61

Burton GW, Devane EM (1953) Estimating heritability in tall fescue (Festuca arundinacea) from replicated clonal material. Agron J 45:478-481

Capistrano-Gossmann G, Ries D, Holtgräw D et al (2017) Crop wild relative populations of Beta vulgaris allow direct mapping of agronomically important genes. Nat Commun 8:1-8. https://doi.org/10.1038/ncomm s15708

Chandrawat KS, Baig KS, Hashmi S, Sarang DH, Kumar A, Dumai PK (2017) Study on genetic variability, heritability and genetic advance in soybean. Int J Pure Appl Biosci 5:57-63

Curruthers A, Oldfield JFT (1961) Methods for the assessment of beet quality. Int Sugar J 63:72-74

Dohm JC, Minoche AE, Holtgräwe D, Capella-Gutiérrez S, Zakrzewski F et al (2014) The genome of the recently domesticated crop plant sugar beet (Beta vulgaris). Nature 505:546-549

Draycott AP (2006) Introduction. In: Draycott AP (ed) Sugar beet. lack Publishing Ltd UK, Oxford, pp 1-8

El-Demardash IS, El-Mouhamady AA, Abdel- Rahman HM, Elewa TA, Aboud KA (2017) Using gamma rays for improving water deficit tolerance in rice. Cur Sci Int 6:321-327

Eldessouky SEl, Heiba SAA, El-Mouhamady AA, Abdel-Tawab YM (2016) DNA fingerprinting and half diallel analysis of some rice genotypes under water deficit conditions. Res J Pharm Biol Chem Sci 7:985-997

El-Mouhamady AA (2009) Breeding for drought tolerance in rice. Ph.DThesis Fac Agric Kafr-Shei Univ Egypt

El-Mouhamady AA, Habouh MAF (2019) Genetic improvement of some rice genotypes for salinity tolerance using generation mean analysis. Cu Sci Int 8:321-348

El-Mouhamady AA, El-Metwally MA (2020) Appreciation of genetic parameters and molecular characterization in some promising accessions of soybean (Glycine max L.). Pak J Biol Sci 23:425-438

El-Mouhamady AA, Ibrahim HF (2020) Elicitation of salt stress-tolerant mutants in bread wheat (Triticum aestivum L.) by using gamma radiation. Bull Natl Res Centre 44:1-18

El-Mouhamady AA, El-Demardash IS, Aboud KA (2010) Biochemical and molecular genetic studies on rice tolerance to salinity. J Am Sci 6:521-535

El-Mouhamady AA, Amer KhA, Ragab AY (2012a) Development of salinity tolerance in some genotypes of barley using line $\mathrm{X}$ tester analysis and some techniques of biotechnology. J Appl Sci Res 8:972-982

El-Mouhamady AA, El-Seidy EH, Aboud KA (2012b) Identification of a molecular markers linked to drought tolerance in some genotypes of Barley. Aust J Basic Appl Sci 6(5):196-204

El-Mouhamady AA, El-Ekhtyar AM, El-Demardash IS (2012C) Molecular markers linked to some traits in Rice. J Appl Sci Res 8:2689-2699

El-Mouhamady AA, Abdel-Sattar AA, El-seidy EH (2013) Assessment of genetic diversity and relationships among canola (Rapeseed) varieties using random amplified polymorphic DNA (RAPD) and specific-PCR analysis. J Appl Sci Res 9:1651-1665

El-Mouhamady AA, El-Seidy EH, Elewa TA, Aboud KA (2014a) Studies on breeding for drought tolerance in some promising lines of sugar beet (Beta vulgaris L.). Mid East J Appl Sci 4:718-732

El-Mouhamady AA, Rady MR, El-Seidy EH (2014b) Assessment of genetic variability for six lines of wheat using physiological traits and molecular markers technique under normal irrigation and water stress conditions. World Appl Sci J 29:506-516

El-Mouhamady AA, Abd-El-Aal SKH, Elewa TA, Aboud KA (2015) Studies on the biotic stress resistance in rice through molecular markers and six population analysis. Int J Curr Microbiol Appl Sci 4:831-854
El-Mouhamady AA, El-Ashary ZM, Mohamed FI, Elewa TA, Aboud KA (2016) Study the effect of water stress conditions on some genotypes of bread Wheat (Triticum aestivum L.) based on morphological, physiological traits and DNA fingerprinting. RJPBCS 5:2065-2077

El-Mouhamady AA, Abdel-Rahman HM, Elewa TA, Aboud KA (2017) Molecular characterization and stability analysis for yield and its components traits in soybean (Glycine max L.). Int J Curr Microbiol Appl Sci 6:1835-1857

El-Mouhamady AA, Abdel-Rahman HM, Rizkalla AA, El-Metwally MA (2019) Assessment of water stress tolerance in wheat genotypes based on half diallel analysis and DNA fingerprinting. Pak J Biol Sci 22:103-116

El-Mouhamady AA, Gad AM, Abdel Karim GSA, Abdel-samea NS, Habouh MAF (2021) Biochemical and molecular genetic markers associated with salinity tolerance in flax (Linum usitatissimum L.). Ann RSCB 25:4828-4844

El-Seidy EH, El-Mouhamady AA, Aboud KA (2013) Studies on the modification of gene expression which responsible for salinity tolerance in some genotypes of wheat. Int J Acad Res Part A 5:23-32

Esmail RM, Abdel Sattar AA, Abdel-samea NS, El-Mouhamady AA, Abdelgany EA, Fathallaha FB (2016) Assessment of genetic parameters and drought tolerance indices in maize diallel crosses. Res J Pharm Biol Chem Sci 7:2409-2428

Farajpour M, Ebrahimi M, Amiri R, Golzari R, Sanjari S (2012) Assessment of genetic diversity in Achillea millefolium accessions from Iran using ISSR marker. Biochem Syst Ecol 43:73-79

Funk A, Galewski P, McGrath JM (2018) Nucleotide-binding resistance gene signatures in sugar beet, insights from a new reference genome. Plant J 95:659-671

Galewski P, Mcgrath JM (2020) Genetic diversity among cultivated beets (Beta vulgaris) assessed via population-based whole genome sequences. BMC Genomics 21:1-14

Galvan MZ, Bornet B, Balatti PA, Branchard M (2003) Inter simple sequence repeat (ISSR) markers as a tool for the assessment of both genetic diversity and gene pool origin in common bean (Phaseolus vulgaris L.). Euphytica 132:297-301

Ganapati RK, Rani R, Karim KMR (2015) Variability, heritability and genetic advance of quantitative traits in sugar beet (Beta vulgaris L.) by effect of mutation. Int J Plant Biol Res 3:1-4

Gomez KA, Gomez AA (1984) Statistical procedures for agricultural research, vol 68, 2nd edn. Wiley, New York

Hamawaki OT, de Sousa LB, Romanato FN, Nogueira APO, Júnior CDS, Polizel AC (2012) Genetic parameters and variability in soybean genotypes. Com Sci 3:76-83

Heiba SAA, Eldessouky SEl, El-Mouhamady AA, El-Demardash IS, AbdelRaheem AA (2016) Use of RAPD and ISSR assays for the detection of mutation changes in wheat (Triticumaestivium L.) DNA induced by ethylmethane sulphonate (EMS). Int J Chem Tech Res 9:42-49

Izadi-Darbandi A, Bahmani K, Ramshini HA, Moradi N (2013) Heritability estimates of agronomic traits and essential oil content in Iranian fennels. J Agric Sci Technol 15:1275-1283

Jaccard P (1908) Nouvelles Researchers Sur La IstributionLorale. Bull Soc Vaud Sci Nat 44:223-270

Johnson HW, Robinson HF, Comstock RE (1955) Estimates of genetic and environmental variability in soybeans. Agron J 47:314-318

Khatab IA, El-Mouhamady AA, Abdel-Rahman HM, Farid MA, El-Demardash IS (2017) Agro-morphological and molecular characterization of sorghum (Sorghum vulgare L.) for water stress tolerance. Int J Curr Res Biosci Plant Biol 4:37-55

Khatab IA, El-Mouhamady AA, Mariey SA, Elewa TA (2019) Assessment of water deficiency tolerance indices and their relation with issr markers in Barley (Hordeum vulgare L.). Curr Sci Int 8:83-100

Li J, Schulz B, Stich B (2010) Population structure and genetic diversity in elite sugar beet germplasm investigated with SSR markers. Euphytica 175:35-42

Manica-Cattani MF, Zacaria JG, Pauletti L, Atti-Serafini A, Echeverrigaray S (2009) Genetic variation among South Brazilian accessions of Lippia alba Mill. (Verbenaceae) detected by ISSR and RAPD markers. Braz J Biol 69:375-380

Mehareb EM, El-Bakary HMY, Abo elenen FFM (2021) Comprehensive evaluation of sugar beet genotypes for yield and relative traits by multivariate analysis. SVU-Int J Agric Sci 3:96-111 
Monteiro F, Frese L, Castro S, Duarte MC, PauloOS LJ, Romeiras MM (2018) Genetic and genomic tools to assist sugar beet improvement: the value of the crop wild relatives. Front Plant Sci 9:1-8

Putnik-Delić M, Maksimović I, Nagl N, Lalić B (2018) Sugar beet tolerance to drought: Physiological and molecular aspects. In: Andjelkovic V (ed) Plant abiotic stress and responses to climate change, pp 389-402. https://doi org/10.5772/intechopen.72253

Ramadan WA, Abdel-Rahman HM, El-Mouhamady AA, Habouh MAF, Aboud KA (2016) Molecular genetic studies on some barley entries for drought tolerance. Int J Pharm Technol Res 9:265-285

Shafie MB, Sayed SM, Hasan Z, Shah RM (2009) Study of genetic variability of Worm wood capillary (Artemisia capillaries) using inter simple sequence repeat (ISSR) in Pahang region, Malaysia. Plant Omics J 2:127-213

Shoaib RM, Abdel-Samea NS, Ramadan WA, Ibrahim MM, Aboud KA (2016) Elucidation of genetic parameters among some selected genotypes of prickly oil lettuce (Lactuca serriolla L.) in Egypt, using morpho-agronomic traits and RAPD markers. RJPBCS 7:1255-1264

Singh D, Mall AK, Misra V, Kumar M, Pathak AD (2018) Assessment of coefficient of variation, correlations between yield and yield attributes in sugar beet (Beta vulgaris L.). Plant Arch 18:15-18
Taski-Ajdukovic K, Nagl N, Curcic Z, Zoric M (2017) Estimation of genetic diversity and relationship in sugar beet pollinators based on SSR markers. Elecron J Biotechnol 27:1-7

Tawfik RS, El-Mouhamady AA (2019) Molecular genetic studies on abiotic stress resistance in sorghum entries through using half diallel analysis and inter-simple sequence repeat (ISSR) markers. Bull Natl Res Centre 43:1-17

Zian AH, El-Demardash IS, El-Mouhamady AA, El-Barougy E (2013) Studies the resistance of lupine for Fusarium oxysporum F. sp Lupini through molecular genetic technique. World Appl Sci J 26:1064-1069

\section{Publisher's Note}

Springer Nature remains neutral with regard to jurisdictional claims in published maps and institutional affiliations.

\section{Submit your manuscript to a SpringerOpen ${ }^{\circ}$ journal and benefit from:}

- Convenient online submission

- Rigorous peer review

- Open access: articles freely available online

- High visibility within the field

- Retaining the copyright to your article

Submit your next manuscript at $\boldsymbol{\nabla}$ springeropen.com 